\title{
Angoulême, 2011
}

The 2011 Festival International de la Bande Dessinée (FIBD) in Angoulême saw the return of enormous crowds to the medieval town in south-western France, and for the first time in many years the event felt uncomfortably crowded and difficult to navigate. This year's edition of the Festival benefited from a lack of major ongoing controversies. Past issues relating to funding from the town and department have been (at least temporarily) resolved, and the construction that disrupted the event for many years in the 2000 s has been complete for some time now. Nonetheless, the show lacked energy and many of the exhibits came across as lacklustre. The major topic of discussion at the show was the strike by salaried employees of L'Association, an occurrence that hung a gloomy cloud over events.

Baru (Hervé Barulea) was the president of this year's festival and the subject of a massive retrospective in the main exhibition space of the Castro Building (or, colloquially, 'the old museum'). This exhibition was not to everyone's taste, though I found it quite compelling, if too dimly lit. More than almost any other French cartoonist, Baru has made the vicissitudes of French working-class life the subject of his art, and the hundreds of original pages on display here were complemented by video projectors showing documentary footage of life on the margins of French society. Baru's career was ably chronicled in a series of displays tracing the development of his style across the length of his career. The show-stopping piece was an enormous glass wall constructed in the middle of the space, with one side featuring blown-up images from books like Les Années Spoutnik ['The Sputnik Years'] (1999-2003), while the other side contained hundreds of pages of art from his award-winning L'Autoroute du soleil ['Highway to the Sun'] (1995) stretching from floor to ceiling. A side room contained the art for his boxing book, L'Enragé ['The Enraged Man'] (2004/2006) alongside film footage of boxers training and sparring. As Baru is known for his love of rockabilly and early rock and roll, the entrance hall leading to his exhibition was filled with the art of dozens of French cartoonists who had produced new 
album covers for classic American songs. A book collecting these images, with an accompanying music $\mathrm{CD}$, was on sale from the Festival.

Upstairs in the Castro Building was one of two important shows featuring the work of Belgian cartoonist Dominique Goblet. The solo retrospective included art from her books Souvenir d'une journée parfaite ['Memory of a Perfect Day'] (2001), Faire semblant c'est mentir ['Pretending is Lying'] (2007), Les Hommes-loups ['The Wolf Men'] (2010) and Chronographie (2010), the book that she published with her daughter, Nikita Fossoul. Pages from a work in progress and enormous pencil drawings and Bic pen drawings rounded out the extremely impressive show. At the Espace Franquin, Goblet was involved in a second exhibition, Génération Spontanée, which focused on cutting-edge and avant-garde comics production among the French-speaking Belgian community. Other artists included in this sizeable show included Judith Forest, Vincent Fortemps, Eric Lambé and several more. This was an impressive gathering of talents, although the show itself was not as formally inventive as the Match de Catch ['Wrestling Match'] exhibition put on the previous year by many of the same artists.

Other shows included in the Festival were barely memorable. The Snoopy and Peanuts exhibition was a series of posters on pedestals outside the Cité International de la Bande Dessinée ('the new museum'). Inside, the permanent exhibition was little altered from last year. The 'Parodies' exposition was divisive. Some appreciated the thematic consistency, while others (myself included) felt that the show relied too heavily on photocopies of work and examples of comic books that are not particularly interesting (like John Byrne's She-Hulk). It was clear that within the space of a year the CIBDI had lost some of its appeal to the crowd, as it was considerably easier to navigate than it had been the year before. Other exhibitions included the entirely unremarkable Le Monde de Troy ['The World of Troy'] in the courtyard of the town hall, a Hong Kong show at the Ateliers Magelis that was too off the beaten path to make a significant impression on visitors and an exhibition of photographs by the Festival's official photographer.

Aside from the exhibitions, the major function of the Festival is retailing. The primary tent on the Place Champ du Mars hosts most of the biggest publishers in Europe, and it was, as always, extremely busy, with lengthy queues to purchase books in many of the publishers' booths, and occasionally enormous lines for superstar artists signing books. Most of the largest publishers have gone to a sort of lottery system for book signings, which makes line management easier but does leave some unlucky visitors feeling cheated out of one of their important experiences. This tent also hosted the manga space this year. Once again, the role of manga at the Festival seems to be evaporating, as, despite the presence of popular manga-ka Riyoko Ikeda, there was almost no significant presence of Japanese comics. 
At the 'Nouveau Monde' tent on the Place New York, which hosts most of the smaller publishers and the fanzine area, the mood on the first two days was muted by the fact that the salaried employees of L'Association, the largest publisher in the space and the one closest to the main entrance, were on strike. The sight of piles of unopened boxes and a table full of leaflets explaining the demands of the employees was a stark reminder for many that the current global economic situation has had a terrible impact on small publishers, and also seemed to signal a shift in the small press away from the days when publishing seemed more like an adventure than a business. Presumably, for L'Association at least, that era has now passed.

Overall, the thirty-eighth edition of the FIBD will not be remembered as among the strongest outings. Though there were some very good exhibitions, there were no excellent ones, and others fell flat. Next year the Festival will welcome an American president for only the third time, as Art Spiegelman has been awarded the Grand Prize. It will be interesting to see if he brings a different sensibility to Europe's best-established and most important comics gathering.

BART BEATY University of Calgary 